\title{
Genetic Diversity of Jatropha curcas in Burkina Faso Revealed by Microsatellite Markers
}

\author{
Kouka Fidele Tiendrebeogo, PhD \\ Nerbewende Sawadogo, PhD \\ Mahamadi Hamed Ouedraogo, PhD \\ Zakaria Kiebre, PhD
}

Ecole Doctorale Sciences et Technologies, Laboratoire Biosciences,

Equipe Génétique et Amélioration des Plantes (EGAP), Université Joseph

KI-ZERBO, Ouagadougou, Burkina Faso

Wend-Pagnangde Marie Serge Felicien Zida, Msc

Institut de l'Environnement et de Recherches Agricoles (INERA), CREAF de

Kamboinsé Département Productions Végétales, Laboratoire de Génétique et de Biotechnologies Végétales, Ouagadougou, Burkina Faso

Kiswendsida Romaric Nanema, PhD

Ecole Doctorale Sciences et Technologies, Laboratoire Biosciences, Equipe

Génétique et Amélioration des Plantes (EGAP), Université Joseph

KI-ZERBO, Ouagadougou, Burkina Faso

Teyoure Benoit Joseph Batieno, PhD

Institut de l'Environnement et de Recherches Agricoles (INERA), CREAF de Kamboinsé Département Productions Végétales, Laboratoire de Génétique et de Biotechnologies Végétales, Ouagadougou, Burkina Faso

\section{Renan Ernest Traore, PhD \\ Pauline Bationo-Kando, PhD \\ Jean-Didier Zongo, Professor \\ Mahamadou Sawadogo, Professor}

Ecole Doctorale Sciences et Technologies, Laboratoire Biosciences, Equipe

Génétique et Amélioration des Plantes (EGAP), Université Joseph

KI-ZERBO, Ouagadougou, Burkina Faso

Doi: 10.19044/esj.2019.v15n15p229 URL:http://dx.doi.org/10.19044/esj.2019.v15n15p229

\begin{abstract}
Jatropha curcas L. is a perennial oleaginous plant commonly used in tropical areas as a medicinal plant in the construction of defensive hedges against animals, and in the fight against water erosion. It produces oil which can be used as agrofuel or soap-making. Despite its potential, the species remain under-exploited and its genetic diversity is still not very well-known
\end{abstract}


in Burkina Faso. This paper focuses on determining the level and structure of the genetic diversity of 50 accessions collected in three phytogeographical sectors of the country using 12 microsatellite markers. Results revealed a total of 37 alleles in the studied population with an average of 3 alleles per locus, a number of 2.717 effective alleles, and a Shannon diversity index of 1.663. Mean observed heterozygosity and mean expected heterozygosity were 0.144 and 0.356 , respectively. Accessions were structured into three genetic groups. The high genetic distance of 0.177 was observed between groups A and B, and a low genetic distance of 0.075 was observed between groups B and C. These preliminary results showed that microsatellites are promising tools that can be used for the characterization of J. curcas. They indicate that the population studied has a low genetic diversity, but it is sufficient to develop programs for conservation and sustainable development of the species.

Keywords: Burkina Faso, genetic variability, Jatropha curcas, SSR markers, under exploited plant

\section{Introduction}

Jatropha curcas L. is a perennial oleaginous plant commonly used in the tropics as a medicinal plant in the construction of defensive hedges against animals, and in the fight against water erosion (Domergue \& Pirot 2008; Chandra Pandey et al., 2012). It produces oil which can be used pure after filtration as fuel in indirect-injection diesel engines or as raw material for biodiesel production by transesterification (Berchmans \& Hirata, 2008; Hamad, 2009). Indeed, J. curcas provides various products that contribute to poverty reduction, including the promotion of income-generating activities mainly for women (sale of seeds and soap) and the valorization of oilcakes as organic fertilizers (Henning \& Ramofafeno, 2005). According to Ouattara (2013), J. curcas is an opportunity for developing countries to improve farmers' incomes and even stimulate the rural economy. Despite the potential of the species, its genetic diversity is still not very known. Indeed, J. curcas is still essentially a wild plant that must be domesticated and genetically improved for its extension (FAO \& IFAD, 2010; Coulibaly et al., 2015). According to Ouattara (2013), the viability of the J. curcas-based biodiesel industry is essentially based on highly productive and oil-rich J. curcas genotypes. Unfortunately, there is very little information on the level of productivity of $J$. curcas in relation to its genetic potential and cultivation techniques. This is because despite strong recommendations for improving the species for intensive production, few references exist on the genetic characteristics of the plant. Previous studies on Burkina' J. curcas was focused on its agromorphological variability (Sama et al., 2013; Tiendrebeogo et al., 2016a), its physiological behavior in the face of stress 
(Ouedraogo et al., 2016), and the oil content of its seeds (Tiendrebéogo et al., 2016b; Sama et al., 2018).

However, having adequate knowledge of the genetic diversity of species is essential for the design of marker-assisted breeding programs (Pecina-Quintero et al., 2011). According to Basha and Sujatha (2007), molecular markers have an advantage over morphological markers in studying the genetic diversity of species. This is because they are unaffected by environmental factors and can provide reliable information. The reliability of information on genetic diversity is essential to optimize conservation and use strategies for plant genetic resources (Bellon et al., 1997). Among the molecular markers, microsatellites or SSRs (Simple Sequence Repeats) have proved effective as a tool for analyzing the genetic diversity of several species. This is as a result of their multi-allelic character, their reproducibility, their codominance, their heritability, their abundance, and their broad distribution in the genome (Gupta \& Varshney, 2000). However, these are DNA sequences consisting of di, tri or tetra-nucleotide motifs repeated in tandem (Morgante \& Olivieri, 1993). Their polymorphism is based on the number of repeating units constituting them. In Burkina Faso, no molecular diversity studies have yet been conducted on J. curcas.

Therefore, this study aimed at obtaining a better knowledge of the genetic diversity of $J$. curcas of Burkina Faso. Specifically, this involves determining the level and structure of genetic diversity using SSR molecular markers.

\section{Materials and Methods}

\section{Plant Material and Molecular Markers Used}

Fifty (50) accessions of J. curcas from three phytogeographic sectors of Burkina Faso (Figure 1) were used for molecular characterization. Twelve (12) microsatellite markers developed by Eurofins MWG Operon were used in this study. These different markers specific to J. curcas have been chosen for their polymorphism as revealed in previous studies (Pamidimarri et al., 2009). The characteristics of the markers used are recorded in Table 1. 


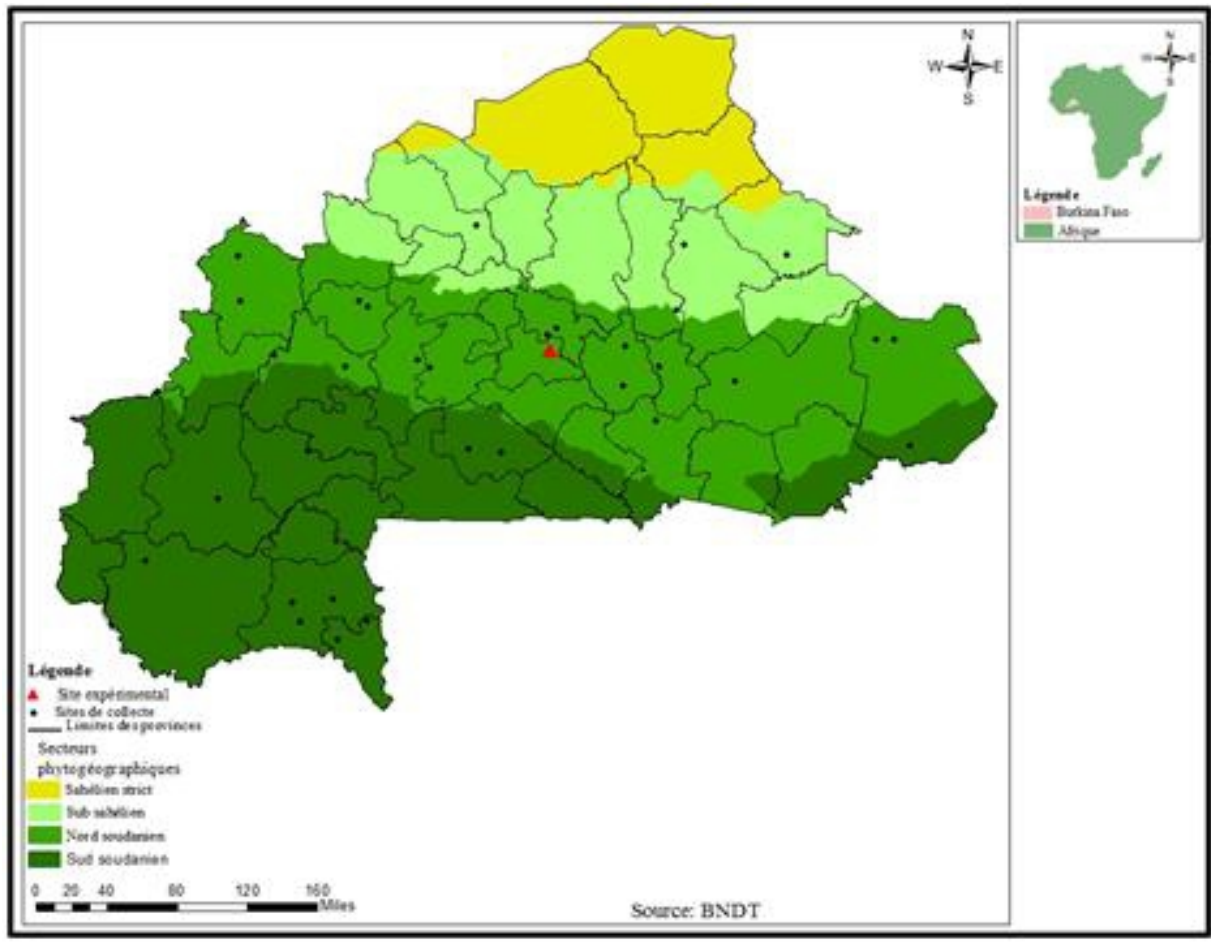

Figure 1. Geographical position of the collection sites of accessions studied

Table 1. Characteristics of the 12 microsatellite markers used in the study

\begin{tabular}{lllll}
\hline $\mathrm{N}^{\circ}$ & Locus & Repeated motifs & TM $\left({ }^{\circ} \mathrm{C}\right)$ & Expected size $(\mathrm{pb})$ \\
\hline 1 & jcds10 & $(\mathrm{TG})_{6} \mathrm{CACGCA}(\mathrm{TG})_{4}$ & 46.5 & $108-122$ \\
2 & jcds24 & $(\mathrm{CA})_{5}(\mathrm{TA})_{8}(\mathrm{CA})_{4} \ldots(\mathrm{TA})_{3} \mathrm{GA}(\mathrm{TA})_{4}$ & 51.0 & $204-216$ \\
3 & jcds41 & $(\mathrm{CA})_{6}(\mathrm{TA})_{2}$ & 56.5 & $102-114$ \\
4 & jcds58 & $(\mathrm{GT})_{4}(\mathrm{GA})_{5}$ & 54.0 & $104-112$ \\
5 & jcds66 & $(\mathrm{CT})_{2}(\mathrm{GT})_{3} \mathrm{ATTGCA}(\mathrm{AT})_{4}$ & 54.0 & $216-228$ \\
6 & jcps1 & $(\mathrm{TG})_{4} \ldots(\mathrm{GT})_{3} \ldots(\mathrm{GT})_{4}$ & 47.5 & $132-162$ \\
7 & jcps6 & $(\mathrm{AT})_{3} \mathrm{G}(\mathrm{TA})_{3} \ldots(\mathrm{CT})_{3} \ldots(\mathrm{GT})_{5} \mathrm{CT}(\mathrm{GT})_{3}$ & 44.0 & $288-380$ \\
8 & jcps9 & $(\mathrm{GT})_{3} \mathrm{GC}(\mathrm{TG})_{2} \mathrm{~A}(\mathrm{GT})_{3}$ & 48.0 & $132-140$ \\
9 & jcps20 & $(\mathrm{TG})_{12}(\mathrm{GA})_{22}$ & 55.0 & $260-278$ \\
10 & jcps21 & $(\mathrm{CA})_{2} \ldots(\mathrm{CA})_{4}$ & 54.8 & $189-208$ \\
11 & jcms21 & $(\mathrm{CA})_{7}$ & 43.0 & $75-89$ \\
12 & jcms30 & $(\mathrm{GT})_{5} \mathrm{~T}(\mathrm{TG})_{2}$ & 48.5 & $135-148$ \\
\hline
\end{tabular}

TM: Hybridization Temperature

\section{Methods}

\section{DNA Extraction}

The DNA extraction was carried out from young leaves of plants installed in the experimental station of the Institute of Rural Development of Gampela based on the methodology used by Sawadogo et al. (2018) and Ouedraogo et al. (2018). For each accession, the young leaves of a plant were harvested, crushed with a pestle and parafilm paper, and immaculated on an 
FTA map. After drying these fingerprints at room temperature, discs about 1 $\mathrm{mm}$ in diameter were punched on these cards. Each disc was washed twice with $200 \mu \mathrm{l}$ of $70 \%$ ethanol and then rinsed twice more with the same amount of Tris EDTA (TE) buffer. The disc was then dried at room temperature and transferred to a PCR tube for amplification.

\section{PCR Amplification}

The PCR reactions were carried out in a final volume of $25 \mu \mathrm{l}$ containing $1 \mu \mathrm{l}$ of the 3 ' primer (forward primer), $1 \mu$ l of the 5' primer (reverse primer), and $18 \mu \mathrm{l}$ of ultra-pure water, $5 \mu \mathrm{l}$ of premix PCR composed of $1 \mathrm{U}$ of Taq DNA polymerase, $250 \mu \mathrm{M}$ dNTP (dATP, dCTP, dGTP, dTTP), $10 \mathrm{mM}$ Tris-HCL ( $\mathrm{pH} 9.0$ ), $30 \mathrm{mM} \mathrm{KCl}, 1.5 \mathrm{mM} \mathrm{MgCl} 2$, and a disk from the FTA map containing the genomic DNA of the accession to be amplified with a concentration ranging from 0.25 to $0.50 \mathrm{ng} / \mu \mathrm{l}$. The PCR amplification was carried out according to a program composed of an initial denaturation phase at $94^{\circ} \mathrm{C}$ for $3 \mathrm{~min}$. This was followed by a series of 35 cycles with denaturation at $94^{\circ} \mathrm{C}$ for $30 \mathrm{~s}$, hybridization with TM during $30 \mathrm{sec}$, and final elongation at $72^{\circ} \mathrm{C}$ for $4 \mathrm{~min}$.

\section{Electrophoresis and Revelation of Bands}

The amplification products were then subjected to electrophoresis at $100 \mathrm{~V}$, on a $10 \%$ polyacrylamide gel in which $15 \mu \mathrm{l}$ of Ethidium bromide $5 \%$ (BET) was added as a fluorescent developer. The migration time was $1 \mathrm{~h} 30$ min in $0.5 x$ Tris Borate EDTA buffer (TBE). The deposits were made in the presence of a molecular weight marker consisting of two microsatellites of different sizes ranging from $50 \mathrm{bp}$ to $1500 \mathrm{bp}$. At the end of the migration, the revelation of the amplified products was made under ultraviolet light. The migration gel was then photographed with a Canon Power Shot A620, 7.1 megapixel camera.

\section{Molecular Data Analysis}

The analysis of the data concerned all the microsatellite markers tested. A binary coding 1 (for band presence) and 0 (for no band) was used for all markers and accessions. Genetic diversity within the $J$. curcas population was analyzed using genetic parameters calculated with the GenALEx version 6.501 and FSTAT V2.9.3.2 softwares.

Thus, to describe the genetic diversity of the collection, eight genetic parameters were calculated. This included the polymorphism rate of the markers $(\mathbf{P})$, the total number of alleles $\left(\mathbf{A}^{\mathbf{t}}\right)$, the average number of alleles per locus (A), the effective number of alleles (Ae), the Shannon diversity index (I), expected heterozygosity (He) or Nei genetic diversity index (D), observed heterozygosity (Ho), and polymorphic information content (PIC). 
The structure of genetic diversity was done using DARwin V6.0 software through the distance array factor analysis (AFTD) and the NeighborJoining classification. These analysis were made from the dissimilarity matrix. The estimation of the index of dissimilarity between the pairs of the different genotypes was carried out according to the simple matching procedure.

\section{Results}

\section{Diversity of SSR Markers Tested and J. Curcas Collection}

The results of the diversity level of the microsatellite markers used in the study are recorded in Table 2 . However, with the exception for the markers jcds10, jcds58, and jcps6 which had one (1) allele, the number of alleles per locus ranged from 2 (jcps 9 and jcms21) to 5 alleles (jcds66 and jcps1) for the other nine markers tested. A total of 37 alleles were identified.

The polymorphism rate of the markers has been estimated at $75 \%$. The effective number of alleles (Ae) varies from 1.537 (jcps9) to 3.786 (jcds66), while the expected heterozygosity $(\mathrm{He})$ is between 0.147 (jcms30) and 0.801 (jcds24). Observed heterozygosity (Ho) ranged from 0.04 (jcms30) to 0.3 (jcps20). The Shannon diversity index (I) varied from 0.979 for the jcps9 marker to 2.503 for the jcds66 marker. The polymorphism information content (PIC) ranged from 0.144 for the jcms30 marker to 0.432 for the jcms 21 marker. The size of the alleles varies from $50 \mathrm{bp}$ for the markers jcds 24 , jcds41, jcds58, jcds66, jcps20, jcms21, and jcms30 to 400bp for the markers jcps20 and jcps21.

The study has also highlighted the existence of genetic diversity within the studied accessions. Consequently, an average of 3.08 alleles per locus, an effective allele number of 2.717 , an expected heterozygosity of 0.356 , an observed heterozygosity of 0.144 , a Shannon diversity index of 1.663 , and a polymorphic information content of 0.289 were obtained.

Furthermore, Figure 2 below shows migration profiles obtained with markers jcds10 (Figure 2A) and jcms21 (Figure 2B).

Table 2. Level of genetic diversity of the 9 markers tested

\begin{tabular}{lllllll}
\hline Locus & $\mathrm{A}^{\mathrm{t}}$ & $\mathrm{Ae}$ & $\mathrm{He}$ & Ho & $\mathrm{I}$ & PIC \\
\hline jcds24 & 3 & 2.085 & 0.801 & 0.060 & 1.260 & 0.261 \\
jcds41 & 4 & 2.724 & 0.250 & 0.140 & 1.586 & 0.245 \\
jcds66 & 5 & 3.786 & 0.331 & 0.100 & 2.503 & 0.324 \\
jcps1 & 5 & 3.364 & 0.243 & 0.220 & 1.926 & 0.237 \\
jcps9 & 2 & 1.537 & 0.327 & 0.120 & 0.979 & 0.320 \\
jcps20 & 4 & 3.419 & 0.400 & 0.300 & 2.290 & 0.390 \\
jcps21 & 5 & 3.400 & 0.264 & 0.140 & 2.117 & 0.250 \\
jcms21 & 2 & 1.787 & 0.441 & 0.180 & 1.244 & 0.432 \\
jcms30 & 4 & 2.351 & 0.147 & 0.040 & 1.070 & 0.144 \\
Moyenne & 3.08 & 2.717 & 0.356 & 0.144 & 1.663 & 0.289 \\
\hline
\end{tabular}

$\mathrm{A}^{\text {t: }}$ total number of alleles, Ae: effective number of alleles, He: expected heterozygosity, Ho: heterozygosity obseved, I: Shannon diversity index, PIC: polymorphism information content 


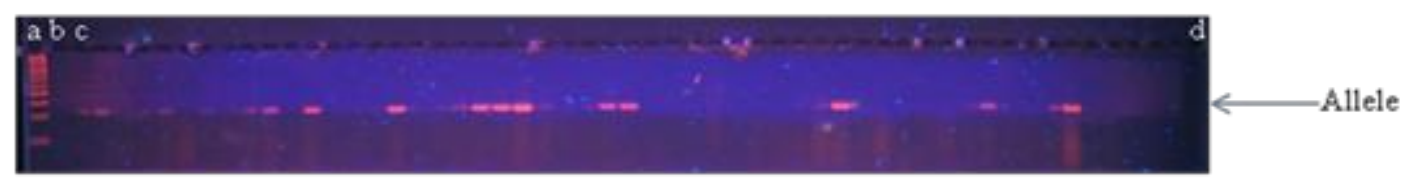

\section{A: jcds 10 marker}

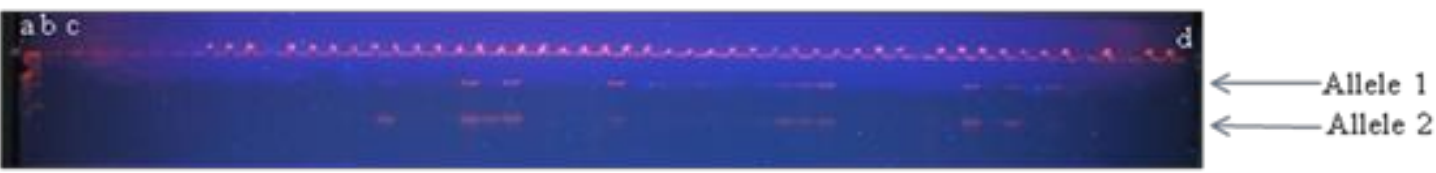

$2 \mathrm{~B}: \mathrm{jcms} 21$ marker

Figure 2. Migration profiles obtained with two markers for 50 accessions a: Molecular weight marker, b: Negative control without DNA, c-d: Samples

\section{Organization of Genetic Diversity}

Genetic structure of $J$. curcas accessions, established using the Neighbor-Joining method (Figure 3), revealed a distribution of J. curcas' accessions into three genetic groups $\mathrm{A}, \mathrm{B}$, and $\mathrm{C}$ which consist respectively of 17, 4 and 29 accessions. Groups $\mathrm{A}$ and $\mathrm{C}$ formed accessions from the three phytogeographic sectors, while group B consisted of accessions from two phytogeographic sectors of the Sudanian domain.

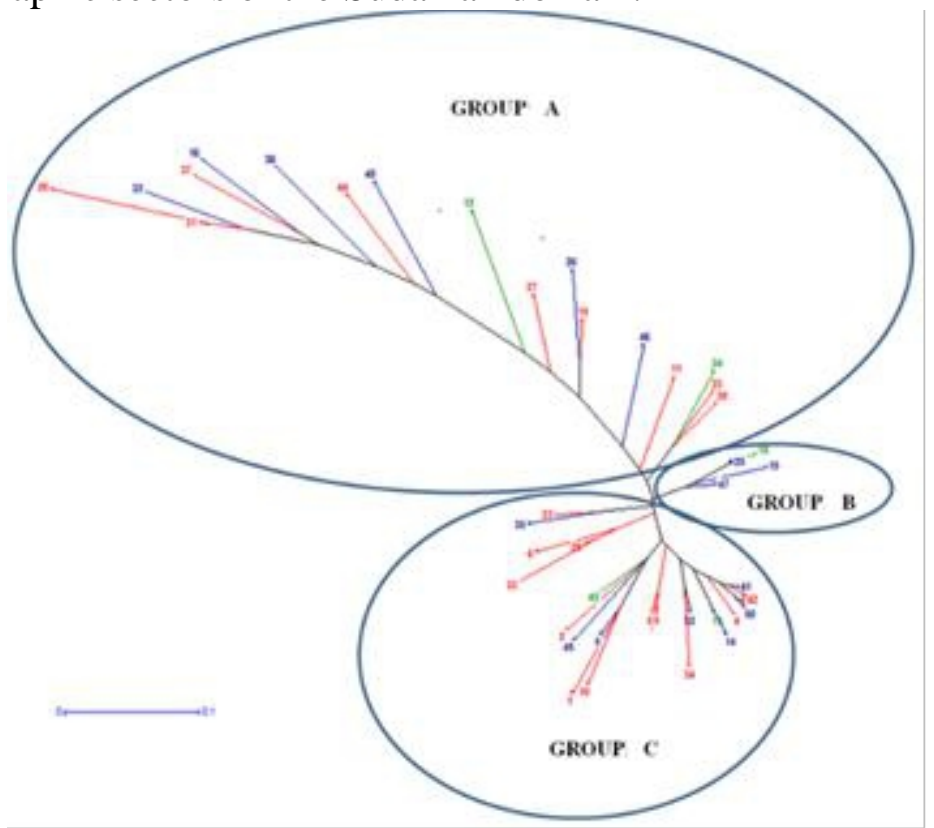

Figure 3. Radial representation of the dendrogram of 50 accessions of $J$. curcas constructed from the matrix of dissimilarities according to the Neighbor-Joining method showing their distribution according to the phytogeographic sectors

Legend: sub-Sahelian (green), northern Sudan (red), southern Sudan (blue) 


\section{Description of Genetic Groups}

The genetic parameters of the three genetic groups obtained from the Neighbor-Joining dissimilarity matrix are shown in Table 3. Group A with an effective number of alleles of 2.56, an expected heterozygosity of 0.403 , a Shannon diversity index of 1.731 , and a PIC of 0.379 showed the highest genetic parameters. However, group B revealed the lowest genetic parameters with an effective number of alleles of 1.675, an expected heterozygosity of 0.112 , a Shannon diversity index of 0.256 , and a polymorphism information potential of 0.084 . On the other hand, group $\mathrm{C}$ presents mean genetic parameters.

Table 3. Distribution of genetic diversity by genetic group

\begin{tabular}{lllll}
\hline Genetic groups & Ae & He & I & PIC \\
\hline Group A & 2.56 & 0.403 & 1.731 & 0.379 \\
\hline Group B & 1.675 & 0.112 & 0.256 & 0.084 \\
\hline Group C & 1.883 & 0.188 & 0.739 & 0.182 \\
\hline
\end{tabular}

Legend: Ae: effective number of alleles, He: expected heterozygosity, I: Shannon diversity index, PIC: polymorphism information content

\section{Differentiation between Genetic Groups}

Genetic distances between the three genetic groups are revealed by Nei's minimum distance and genetic pairwise. Genetic group differentiation is recorded in Table 4. Genetic differentiation (Fst) showed a significant difference between groups. The highest Nei minimal genetic distance $(0.177)$ was observed between genetic groups $\mathrm{A}$ and $\mathrm{B}$. The largest index of differentiation (Fst) of 0.341 is obtained between groups $\mathrm{A}$ and $\mathrm{C}$, while the lowest value of 0.2315 was obtained between groups A and B.

Table 4. Genetic differentiation between Genetic groups

\begin{tabular}{cccc|ccc}
\hline Genetic & \multicolumn{3}{c|}{ Minimal distance of Nei } & \multicolumn{3}{c}{ Differentiation index Fst } \\
\cline { 2 - 6 } groups & Group A & Group B & Group C & Group A & Group B & Group C \\
\hline Group A & 0 & & 0 & & \\
Group B & 0.177 & 0 & & $0.2315^{*}$ & 0 & \\
Group C & 0.171 & 0.075 & 0 & $0.3415^{* *}$ & $0.2791^{* *}$ & 0 \\
\hline \multicolumn{6}{r}{}
\end{tabular}

\section{Discussion}

The $75 \%$ polymorphism rate observed in this study is lower than the $100 \%$ level obtained by Pamidimarri et al. (2009). Nonetheless, it is superior to the $58.33 \%$ polymorphism observed by Pamidimarri et al. (2008) with the same SSR markers. Of the twelve markers tested in this study, three markers (jcds66, jcps1, jcps21) were the most polymorphic with 5 alleles each. This is in contrast to Pamidimarri et al. (2008) who observed a much higher polymorphism with markers jcds24, jcms30, and jcps6. Ouattara (2013) has also shown on Senegalese accessions that these twelve SSR markers are all monomorphic. The PIC of an SSR marker that takes into account not only the 
number of alleles detected but also the relative frequency of each allele is an important estimate of the discriminant power of this marker (Smith et al., 2000). According to Bostein et al. (1980), the PIC can be high (PIC>0.5), moderate $(0.25<\mathrm{PIC}<0.5)$ or low (PIC <0.25). Thus, $66.67 \%$ of the markers tested have a moderate PIC against $33.33 \%$, which have a low PIC. The most discriminating markers are jcds10, jcds58, and jcms21 with PIC values greater than 0.4. The mean value of the PIC in this study (0.289) is greater than that of Maurya et al. (2013) which are 0.24 and 0.28 respectively with SSR markers enriched in CA and GA. Nevertheless, this is lower than the value obtained by Vischi et al. (2013) which is 0.36. This author, furthermore, showed that jcms 21 is the most discriminating with a PIC value of 0.38 . Hence, this is a value lower than that obtained with the same marker in this study which is 0.43 .

The values of the Nei diversity index or expected heterozygosity that varied from 0.14 to 0.8 are lower than those obtained by Pamidimarri et al. (2009) with the same SSR markers. According to Bressan et al. (2012), there are other SSR markers that are 0.56 to 0.95 and 0.25 to 0.86 , respectively. Sanou et al. (2015) also obtained, with SSR markers, lower values between 0 and 0.548 on Mexican populations of J. curcas, and even lower values between 0 and 0.005 for African and Asian samples. Observed heterozygosity values ranging from 0.04 to 0.3 are lower than values between 0.54 and 0.94 obtained by Pamidimarri et al. (2009) with the same SSR markers. In addition, there are also values ranging between 0 and 0.591 obtained by Sanou (2012) with other SSR markers on Mexican populations of J. curcas. The number of alleles per study locus that ranged from 1 to 5 is close to the results reported in previous studies of $J$. curcas (Pamidimarri et al., 2008; Na-ek et al., 2011; Maurya et al., 2013) which are respectively 1 to 4,2 to 4 , and 2 to 5. With 37 alleles detected on the 50 accessions (an average of 3 alleles per marker), the collection of $J$. curcas from Burkina Faso is globally undiversified. Indeed, the work of Sanou et al. (2015) on accessions of J. curcas revealed low genetic diversity in Africa and Asia continents where the species was introduced by Portuguese navigators. These authors have also shown that Mali's accessions are monomorphic. Ouattara (2013) also showed that Senegal's accessions are monomorphic. Compared to Mali and Senegal, Burkina Faso accessions appear more polymorphous. The structure of the genetic diversity of Burkina Faso forge in three genetic groups differs from the distribution into two genetic groups. This was highlighted by Santos et al. (2016) out of 109 germplasm accessions from the University of Florida. Of the three genetic groups established from the Neighbor-Joining dissimilarity matrix, genetic groups A and $\mathrm{C}$ are the most diverse. This could be explained by the fact that they contain accessions from the three phytogeographic sectors. Genetic group B is the most homogeneous because it contains accessions originating from two 
phytogeographic sectors belonging to the Sudanian domain. Similar results have been reported by Sunil et al. (2010). Furthermore, low genetic diversity and the lack of structuring of diversity by geographical origin confirm the hypothesis that $J$. curcas is an introduced species (Ouattara, 2013). The low genetic diversity observed in this study and in other studies could result from a particular reproductive system called apomixis (the ability of a plant to produce an embryo without sexual reproduction) that potentially binds alleles at each locus and limits genetic recombination. Indeed, the cytometric analysis performed by Ambrosi et al. (2010) showed the existence of nongametophytic apomixis in $J$. curcas. Autogamy, which is a reproductive system less rich in genetic diversity than allogamy, has also been reported in J. curcas by Dhillon et al. (2006). In addition, Santos et al. (2016) showed that the accessions of localities outside the center of origin (Mexico and Costa Rica) are even less diversified. Therefore, the low genetic diversity of $J$. curcas would also be linked to evolutionary processes. According to these authors, this species may have suffered a genetic drift over time. According to Heller (1996), J. curcas was the victim of a founder effect during its diffusion to Asia and Africa by Portuguese mariners. This was due to the small sample size which was not a representative of the original natural population. Achten et al. (2010) also hypothesized that the complex history of introduction and domestication in other continents contributed to the low level of genetic diversity observed in this species. According to Veasey et al. (2011), the effect of a bottleneck that occurs when the size of a population is significantly reduced due to the man-made (agronomic or non-agronomic) selection process could also explain this low diversity. The existence of anthropogenic actions that have reduced $J$. curcas population is supported by Ambrosi et al. (2010), who indicated that the species were first selected for their productivity characteristics. Therefore, the formation of new variability will probably not be possible, even with cross fertilization (allogamy), in isolated environments colonized by very similar accessions. This may have caused the high genetic similarity between accessions in new habitats. The low level of genetic diversity is also linked to the vegetative propagation method used by former farmers. According to Ovando-Medina et al. (2011), vegetative propagation has been practiced for centuries to ensure the spread of the species in rural areas. Thus, some selected accessions have spread widely as clones. According to Ouattara (2013), the exchange of cuttings between relatives and friends would have favored the dispersal of the species in Senegal. Indeed, the toxicity of the seeds of $J$. curcas prevents their dissemination by animals and the action of the wind seems limited because of the ovoid shape of the fruit and its weight which is greater than $1.5 \mathrm{~g}$ (Heller, 1996). 


\section{Conclusion}

The study revealed a low genetic diversity within the J. curcas collection of Burkina Faso. The twelve microsatellite markers tested showed a low number of alleles ranging from 1 to 5. In total, 37 alleles were detected in this study. Also, jcms21 marker was the most informative on the genetic diversity of $J$. curcas from Burkina Faso and three genetic groups was established. The narrowness of the genetic base revealed by the study limits the possibilities for improving the species from local plant material. Hence, there is the need to broaden the genetic base of the species in Burkina Faso through introductions from the center of origin.

\section{Conflict of Interests}

The authors have not declared any conflict of interests.

\section{Acknowledgements}

The authors wish to thank the heads of "Laboratoire de Génétique et Biotechnologies Végétales" of CREAF technical support and the members of the "Laboratoire Biosciences of the Université Ouaga I Pr Joseph KI-ZERBO" for the technical, financial assistance, and corrections done on the manuscript.

\section{References:}

1. Achten, W. M .J., Nielsen, L.R., Aerts, R., \& Lengkeek, A.G. (2010). Towards domestication of Jatropha curcas. In Biofuels, 1: 91-107.

2. Ambrosi, D.G., Galla, G., Purelli, M., \& Barbi, T. (2010). DNA Markers and FCSS analyses shed light on the genetic diversity and reproductive strategy of Jatropha curcas L. Diversity (Basel) 2: 810836.

3. Basha, S.D. \& Sujatha, M. (2007). Inter and intra-population variability of Jatropha curcas (L.) characterized by RAPD and ISSR markers and development of population-specific SCAR markers. In Euphytica, 156: 375-386.

4. Bellon, M.R., Pham, J.L., \& Jackson, M.T. (1997). Genetic conservation: a role for rice farmers. In: Maxtead N., Ford-Loyd B.V. and Hawkes G.J. (eds.) Plant conservation: The in situ approach. London: Chapman and Hall, 263-289.

5. Berchmans, H.J. \& Hirata, S. (2008). Biodiesel production from crude Jatropha curcas L. seed oil with a high content of free fatty acids. In Bioresource Technology, 99: 1716-1721.

6. Botstein, D., White, R.L., Skolnick, M., \& Davis, R.W. (1980). Construction of genetic linkage Map in man using Restriction Fragment Length Polymorphisms. In American Journal of Human Genetics, 32: 314-331. 
7. Bressan, E.D.A., Scotton, D.C., Ferreira, R.R., \& Jorge, E.C. (2012). Development of microsatellite primers for Jatropha curcas (Euphorbiaceae) and transferability to congeners. In American Journal of Botany, 99: 237-239.

8. Chandra Pandey, V., Singh, K., Singh, S.J., Kumar, A., Singh, B., \& Singh, R.P. (2012). Jatropha curcas: A potential biofuel plant for sustainable environmental development. In Renewable and Sustainable Energy Reviews, 16: 2870-2883.

9. Coulibaly, N.D., Koné, D., Soro, D., \& Kouadio, Y.J. (2015). Caractérisation physiologique de dix accessions de Jatropha curcas dans deux zones pédoclimatiques assez contrastées de la Côte d'Ivoire. In European Sientific Journal, 11: 61-77.

10. Dhillon, R.S., Hooda, M.S., Handa, A.K., Ahlawat, K.S., \& Kumar, Y. (2006). Clonal propagation and reproductive biology of Jatropha curcas L. In Indian Journal of Agroforestry, 8, 18-27.

11. Domergue, M. \& Pirot, R. (2008). Jatropha curcasL. Rapport de synthèse bibliographique. CIRAD, AGRO generation, $188 \mathrm{p}$.

12. FAO \& FIDA (2010). Le Jatropha, une culture bioénergétique pour les pays pauvres. Rapport, $4 \mathrm{p}$.

13. Gupta, P.K. \& Varshney, R.K. (2000). The development and use of microsatellite markers for genetic analysis and plant breeding with emphasis on bread wheat. In Euphytica, 113: 163-185.

14. Hamad, B. (2009). Transestérification des huiles végétales par l'éthanol en conditions douces par catalyses hétérogènes acide et basique. Thèse de doctorat, Université Claude Bernard-Lyon 1, France, 197 p.

15. Heller, J. (1996). Physic nut (Jatropha curcas L.) in Promoting the conservation and use of underutilized and neglected crops. International Plant Genetic Resources Institute (IPIGRI), 1, pp. 1-66.

16. Henning, R. \& Ramofafeno, T. (2005). Eclairage avec de l'huile de Jatropha. PLAE-Atelier de démonstration à Marovoay.

17. Martynov, S.P., Dobrotvorskaya, T.V., Dotlacil, L., Stehno, Z., Faberova, I., \& Bares, I. (2003). Genealogical approach to the formation of the winter wheat core collection. In Russian Journal of Genetics, 39 (8): 917-923.

18. Maurya, R., Gupta, A., Singh, S.K., Rai, K.M., Chandrawati Sawant, S.V., \& Yadav, H.K. (2013). Microsatellite polymorphism in Jatropha curcas L. A biodiesel plant. In Industrial Crops and Products, 49: 136142.

19. Morgante, M. \& Olivieri, A.M. (1993). PCR-amplified microsatellites as markers in plant genetics. In Plant Journal, 3 (1): 175-182. 
20. Na-ek, Y., Wongkaew, A., Phumichai, T., Kongsiri, N., Kaveeta, R., Reewongchai, T., \& Phumichai, C. (2011). Genetic Diversity of Physic Nut (Jatropha curcas L.) Revealed by SSR Markers. In Journal of Crop Sciencce and Biotechnoloy 14 (2) : $105 \sim 110$. DOI No. 10.1007/s12892-011-0008-4

21. Ouattara, B. (2013). Etude de la diversité génétique, de la variabilité agro-morphologique et éco-physiologique de Jatropha curcas L. au Sénégal. Thèse de doctorat unique, Université Cheich Anta Diop de Dakar, $120 \mathrm{p}$.

22. Ouédraogo, M.H., Sawadogo, N., Batieno, T.B.J., Zida, W.M.S.F., Bougma, A.L., Barro, A., Kiébré, Z., \& Sawadogo, M. (2018). Evaluation of genetic diversity of okra accessions [Abelmoschus esculentus (L. Moench)] cultivated in Burkina Faso using microsatellite markers. In African Journal of Biotechnology 17(5), 126-132. DOI: 10.5897/AJB2017.16336.

23. Ouédraogo, R.F., Gnoula, C., Karou, S.D., Zombré, G., \& Simporé, J. (2016). Comparative Effects of Light and Water Stresses on Antioxidant Enzymes Activity of Three Ecotypes of Jatropha curcas Seedlings. In Annual Research \& Review in Biology 10(5): 1-10.

24. Ovando-Medina, I., Espinosa-García, F. J., Núñez-Farfán, J.S., \& Salvador-Figueroa, M. (2011). State of the art of genetic diversity research in Jatropha curcas. In Scientific Research and Essays, 6(8): 1709-1719.

25. Pamidimarri, D.V.N.S., Singh, S., Mastan, S.G., Patel, J., \& Reddy, M.P. (2008). Molecular characterization and identification of markers for toxic and non-toxic varieties of Jatropha curcas L. using RAPD, AFLP and SSR markers. In Molecular Biology Reports, 8 p.

26. Pamidimarri, D.V.N.S., Sinha, R., Kothari, P. \& Reddy, M.P. (2009). Isolation of novel microsatellites from Jatropha curcas L. and their cross-species amplification. Molecular Ecology Resources, 9: 431433.

27. Pecina-Quintero, V., Anaya-Lopez, J.L., Colmenero, A.Z., \& Garcia, N.M. (2011). Molecular characterisation of Jatropha curcas L. genetic resources from Chiapas, México through AFLP markers. In Biomass and Bioenergy, 35: 1897-1905.

28. Sama, H., Yélémou, B., Hilou, A., Rasolodimby, JM., \& Hien, V. (2013). Jatropha curcas in Burkina Faso : chemical characteristics of seeds and genetic variability of its ecotypes for better adaptability to the needs of populations. In European Journal of Experimental Biology 3(6):276-284.

29. Sama, H., Ouattara, B., Hilou, A., Derra, A. N., Yélémou, B., \& Hien, V. (2018). Variability of morpho-metric traits and oleaginous biofuel 
potential of Jatropha curcas L. (Euphorbiaceae) seeds in Burkina Faso. In African Journal of Agricultural Research 13(52): 2911-2918. DOI: $10.5897 / A J A R 2018.13196$.

30. Sanou, D.H. (2012). Domestication de Jatropha curcas pour la production de biocarburant au Mali. Atelier de capitalisation de connaissances et savoir-faire sur les filières des biocarburants. Ministère de l'Agriculture, Institut d'Economie Rurale, Centre Régional de Recherche Agronomique de Sotuba, 28 p.

31. Sanou, H., Angulo-Escalante, M.A., Martínez-Herrera, J., \& Koné, S. (2015). Loss of genetic diversity of Jatropha curcas L. through domestication: implications for its genetic improvement. In Crop Science, 55: 749-759.

32. Santos, D.N., Ferreira, J.L., Pasqual, M., Generoso, A.L., Setotaw, T.A., Cançad, G.M.A., \& Vendrame, W.A. (2016). Population structure of Jatropha and its implication for the breeding program. In Genetics and Molecular Research, 15 (1), 11p.

33. Sawadogo, N., Batiéno, T.B.J., Kiébré, Z., Ouédraogo, M.H., Zida, W.P.M.S.F., Nanéma, K.R., Nebié, B., Bationo-Kando, P., Traoré, R.E., Sawadogo, M., \& Zongo, J.D. (2018). Assessment of genetic diversity of Burkina Faso sweet grain sorghum using microsatellite markers. In African Journal of Biotechnology , 17(12), 389-395. DOI: 10.5897/AJB2017.16344,

34. Smith, J.S.C., Kresovich, S., Hopkins, M.S., Mitchell, S.E., Dean, R.E., Woodman, W.L., Lee, M., \& Porter, K. (2000). Genetic diversity among elite sorghum inbred lines assessed with simple sequence repeats. In Crop Science, 40: 226-232.

35. Sunil, N., Sujatha, M., Kumar, V., Vanaja, M., Basha, S.D., \& Varaprasad, K.S. (2010). Correlating the phenotypic and molecular diversity in Jatropha curcas L. In Biomass and bioenergy, 35: 10851096.

36. Tiendrébéogo, K.F., Sawadogo, N., Nanéma, K.R., Traoré, R.E., Bationo-Kando, P., Zongo, J.D., \& Sawadogo, M. (2016a). Evaluation de la diversité génétique du pourghère (Jatropha curcas L.) au Burkina Faso. In International Journal of Innovation and Applied Studies 16 (1): 155-165..

37. Tiendrébéogo, K.F., Sawadogo, N., Nanema, K.R., Traore, R.E., Bationo-Kando, P., Ouedraogo, M.H., \& Sawadogo, M. (2016b). Evaluation of morpho-metric characteristics of fruits and oil content of seeds of Jatropha curcas L. in Burkina Faso. In International Journal of Plant, Animal and Environmental Science 6 (2):145-155. DOI: 10.21276/Ijpaes. 
38. Veasey, E. A., Piotto, F.A., Nascimento, W.F., \& Rodrigues, J.F. (2011). Processos evolutivos e a origem das plantas cultivadas. In Ciencia Rural, 41: 1218-1228.

39. Vischi, M., Raranciuc, S., \& Baldini, M. (2013). Evaluation of genetic diversity between toxic and non toxic Jatropha curcas L. accessions using a set of simple sequence repeat (SSR) markers. In African Journal of Biotechnology, Vol. 12 (3), pp. 265-274. 